\section{EPIDEMIC CATARRHAL JAUNDICE.}

BY E. A. COCKAYNE, M.D. Oxon., M.R.C.P. LoND., ASSISTANT PHYSICIAN TO THE MIDDLESEX HOSPITAL; PHYSICIAN TO OUT-PATIENTS, VICTORIA HOSPITAL FOR CHILDREN, CHELSEA.

IN September, 1913, after seeing no cases of catarrhal jaundice since the early spring, I began to meet with them amongst my out-patients, and they were fairly numerous until the middle of March, 1914, but for the last three months I have seen none. By making inquiries about the possibility of contact with other cases I found that in two instances they had occurred in connexion with definite epidemics.

In 1912 I published a paper on this subject in the Quarterly Journal of Medicine in which I tried to prove that catarrhal jaundice should be classed with measles and mumps as one of the specific infectious diseases due to an unknown organism, and that it should be regarded as an infective hepatitis. I am convinced more than ever that this is a correct view, and have been supported by Dr. Leonard Guthrie in a paper read before the Section for the Study of Disease in Children of the Royal Society of Medicine. I will not repeat all the arguments there brought forward, but will content myself by giving a few of the most striking.

The disease has an almost worldwide distribution, a definite seasonal and age incidence, and is commoner in some seasons than others. The fact that one attack confers immunity for life also points to its specific nature. Fewer than 40 epidemics have been described in this country, but when the view that the disease is not an incident in a non-specific gastro-enteritis is less widely held, small epidemics will probably be found to be fairly common, and small groups of two or three cases will be noticed still more frequently. I pointed out that though the clinical features of sporadic cases vary to some extent, none are met with which are not also seen in the epidemics and vice versa; the ages and seasonal incidence show a very close parallel, and the geographical distribution of epidemics closely follows that of sporadic catarrhal jaundice, though it is not quite so extensive. No doubt the gaps will soon be filled when greater interest is aroused; for instance, though the sporadic form is met with, no epidemics have been recorded from Canada, but Dr. C. H. Reason told me a few months ago that he met with one affecting about 20 children near Toronto.

It is still an open question whether the disease is a local one of the bile-ducts and liver or a general blood infection. With growing knowledge many diseases formerly regarded amongst the former class are now placed in the latter, and several considerations suggest that this should be one of them. Such are the prodromal period of malaise with pains in the head and limbs, the enlargement of the spleen, and the albuminuria, which are frequent in some epidemics, and also occur in isolated cases. The rare fatal cases met with in epidemics are inseparable on clinical and pathological grounds from acute yellow atrophy of the liver, and the seasonal incidence of this disease appears to be the same. It is noteworthy that three cases have occurred in London at the end of 1913 and the beginning of 1914, during the time catarrhal jaundice has been unusually common, one in a child recorded by Dr. J. Porter Parkinson, and two in adults by Dr. W. Brander and Mr. G. L. Keynes.
Recently collected evidence seems to prove that the disease is contracted by breathing in air con. taining the organism, and close contact is necessary. In a few cases I have noticed a definite pharyngitis, and $I$ published some instances in 1912. In 1913 I met with another example in a girl aged $5 \frac{1}{2}$ years. She had pharyngitis and slight malaise on Nov. 4th, and on the 15th urticaria began, such that the mother said "she could not bear herself." On the 18th she vomited twice, and jaundice appeared on the 19th and lasted until the 26th. Sore-throat with marked redness of the pharynx was noticed in one of the epidemic cases (Table II., Case 4). Ralph Poignard noticed slight pharyngitis in every case in a small epidemic in children between the ages of 6 and 12 years. Dr. Cameron Gibson, who has recently published a paper, noticed sore-throat with symptoms of a "cold" in one case, and says that there were an unusual number of cases of pharyn. gitis in children during epidemics of jaundice at Lymm and Bickerton. This suggests that the tonsils and pharynx are the portals of entry of the infecting organisms, as in so many specific fevers, though they do not necessarily cause a recognisable inflammation of the tissues during their passage.

Several interesting points are brought out in the two epidemics which I have just seen. The first. occurred at the Algernon-road School, Hendon. In this 10 children were attacked, 4 boys and 6 girls, The first case occurred in one of the older children; all the rest in the children attending the infants' department. Boys and girls are taught together, but the buildings for the older children and infants are in separate blocks at opposite ends of the play. ground.

The district is a somewhat isolated one and the children attending the school have clean and comfortable homes. West Hendon is supplied by two water companies, the Colne Valley and the West Middlesex, and about half the children affected come from houses supplied by the one and about half from those supplied by the other. Nor did the children have milk from a common source. Water is supplied at the school, but while the epidemic was in progress the weather was cold and

TABLE I.-Giving Particulars of 10 Cases of Catarrhal Jaundice occurring in the Algernon. road School, Hendon.

\begin{tabular}{|c|c|c|c|c|c|}
\hline No. & $\begin{array}{l}\text { Sex } \\
\text { and } \\
\text { age. }\end{array}$ & $\begin{array}{c}\text { Date of absence from } \\
\text { school. }\end{array}$ & No. & $\begin{array}{l}\text { Sex } \\
\text { and } \\
\text { age. }\end{array}$ & $\begin{array}{c}\text { Date of absence from } \\
\text { school. }\end{array}$ \\
\hline 1 & F., 9 & Dec. 1 to Dec. 25. & 6 & M., 5 & Jan. 7 to Jan. 19. \\
\hline 2 & F., 6 & , 11 ,, Jan. 7. & 7 & F., 6 & , $9,,, 19$. \\
\hline 3 & M., 5 & , $17,, \quad$, & 8 & M., 5 &, 16 \\
\hline 4 & F., 6 & , $31, \quad, \quad 19$. & 9 & M., 6 & Feb. 11 ,, Feb. 27. \\
\hline 5 & F., 6 & Jan. 7 , , & 10 & F., 7 & Mar. 2 ,, Mar.31. \\
\hline
\end{tabular}

most of the children live very near the school, so that little water was being drunk. Inquiry also showed that some of the affected children had not been using it at all. This disposes of the possibility that water or milk could have conveyed the infection. Many of the children attacked were members of the same class and, after the first case, all were infants.

There is little doubt that the disease was conreyed from child to child by the air, while they were in school, or in the room in which hats and coats were hung. There was no influenza, typhoid, or other kind of illness affecting the school or 
neighbourhood at the time, and there were no cases of catarrhal jaundice in the other schools of the district or amongst the general population round about.

Dr. M.I. Baker, who attended all the cases except two, which I saw myself, says they were mild with one exception. In this case there was severe initial romiting, and pyrexia, $101^{\circ} \mathrm{F}$. for four days. The urine contained a trace of albumin, which disappeared after a fortnight. There was a good deal of pain in the hepatic region and the liver was enlarged. In the two cases which I treated the temperatures were $98^{\circ} 4^{\circ}$ and $98^{\circ} 8^{\circ} \mathrm{F}$., and the pulserates 102 and 104 respectively, though bile salts as well as bile pigment were present in the urine. I have several times found a quickened pulse during the time bile salts were present in the urine, and in common with all other observers have failed to find slowing of the pulse in catarrhal jaundice in children. The liver was enlarged in both cases, but the spleen was not palpable. As the jaundice was disappearing the girl patient complained of itching when warm in bed, an unusual symptom in a child in the absence of urticaria.

There were no prodromal symptoms in any of the cases; there were nausea, vomiting, and anorexia about two days before the jaundice was evident, but at this stage the liver is presumably already inflamed.

One child complained spontaneously of xanthopsia, an interesting symptom and one whose occurrence has been denied by some authors.

The second epidemic, which differed considerably from the first, was at the Bridge School, Wealdstone, about five miles away from the Hendon school. Twelve school children were affected, and three mothers and four younger children caught the infection from children attending the school. There were no cases in other schools of the district, nor any isolated cases, so far as could be discovered, nor could any connexion between the two outbreaks be established.

Table II. gives the age, sex, and class of each child and the clinical details which were procurable. Great interest attaches to the rapidity with which the epidemic spread. All the 12 children were attacked within a period of 12 days, and the incubation period must have been very short $(1,2$, and 3 days); whereas in the Hendon epidemic between the first and second cases there was an interval of 10 days, and between the cases of the brother and sister attacked (the latter probably infected by the former) 14 days; between the eighth and ninth and ninth and tenth cases, '26 and 19 days respectirely elapsed. The longer incubation period may have been correlated with the lesser virulence. When I had the disease myself the incubation period cannot have been longer than three or four days. Cameron Gibson gives 3-14 days, but noticed intervals of 27 and 47 days in two instances. The very long intervals sometimes noticed may be explained by abortive cases being overlooked, or by the virus remaining active in a room and infecting a child indirectly.

In the Wealdstone school the girls have the upper floor, a central hall with class-rooms round it, and the boys the lower, to which a separate staircase gives access. There are no mixed classes. The first four cases occurred in one class-room, and affected children sitting at desks placed next to one another. Fringuet noticed a parallel phenomenon in a school epidemic, in which three boys and two girls, who sat at neighbouring desks, were attacked in turn.
Here again the general water-supply cannot be incriminated, and at the school little water was being drunk, and in any case the boys seldom use the cup provided, usually drinking it from their hands. With one exception the homes of the children attacked were good ones.

In this epidemic the first, sixth, eighth, and tenth, and possibly the twelfth, cases must have been abortive ones-namely, cases in which no jaundice developed. In one of these it was proved

TABLE II.-Giving Particulars of 12 Cases of Catarrhal Jaundice occurring in Bridje School, Wealdstone.

\begin{tabular}{|c|c|c|c|c|c|}
\hline 恋 & 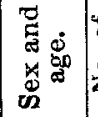 & 苍这. & $\begin{array}{l}\text { Date of } \\
\text { onset. }\end{array}$ & $\begin{array}{l}\text { Other } \\
\text { cases in } \\
\text { same } \\
\text { house. }\end{array}$ & Character of illness. \\
\hline 1 & F., 8 & $2 \mathbf{A}$ & Feb. 25 & - & $\begin{array}{l}\text { Vomited for several hours, bringing } \\
\text { up green mucus. Headache an } \\
\text { dizziness; no jaundice. }\end{array}$ \\
\hline 2 & F., 8 & $2 A$ & Feb. 26 & $\begin{array}{l}\text { Mother } \\
\text { and } 3 \\
\text { younger } \\
\text { children. }\end{array}$ & $\begin{array}{l}\text { Sudden onset with severe vomiting } \\
\text { of yellow mucus, rigors and pyrexia } \\
\text { Pain in hepatic region. Furred } \\
\text { tongue and sordes on lips; deep } \\
\text { jaundice. Loss of weight, prolonged } \\
\text { convalescence. Mother also had } \\
\text { severe attack. }\end{array}$ \\
\hline 3 & F., 7 & $2 \Delta$ & " 27 & 一 & $\begin{array}{l}\text { Feb. } 27 \text { : Malaise. Feb. 28: Jaundice } \\
\text { of conjunctive. March 1: Deep } \\
\text { jaundice for } 3 \text { weeks. March } 4 \text { : } \\
\text { Much bile pigment; trace of bile } \\
\text { salts in urine; albuminuria. Liver } \\
\text { two fingers breadth below costal } \\
\text { margin. Spleen not felt. Hereditary } \\
\text { ichthyosis of skin; on appearance of } \\
\text { jaundice some itching. Six weeks } \\
\text { after onset still easily tired. }\end{array}$ \\
\hline 4 & F., 8 & $2 \Delta$ & Mar. 2 & - & $\begin{array}{l}\text { Nausea, no vomiting; sore-throat; } \\
\text { furred tongue. Jaundice lasted } \\
\text { about a fortnight. }\end{array}$ \\
\hline 5 & M., 11 & 2 & , 2 & Mother. & $\begin{array}{l}\text { Vomiting, dizziness, and headache. } \\
\text { Sordes on lips. Slight jaundice of } \\
\text { conjunctivæ. Mother had slight } \\
\text { attack some days later. }\end{array}$ \\
\hline 6 & M., 9 & & ", 2 & - & $\begin{array}{l}\text { Headache; some pain in hepatic } \\
\text { region; no jaundice. }\end{array}$ \\
\hline 7 & M., 8 & 5 & , & - & $\begin{array}{l}\text { Vomiting of green mucus; headache ; } \\
\text { slight jaundice of conjunctivæ. }\end{array}$ \\
\hline 8 & M., 9 & 4 & $"$, & 一 & $\begin{array}{l}\text { Vomiting of green mucus; headache; } \\
\text { no jaundice. }\end{array}$ \\
\hline 9 & M., 10 & 4 & $"$ & $\begin{array}{l}\text { Mother } \\
\text { and } \\
\text { brother. }\end{array}$ & $\begin{array}{l}\text { Giddiness; headache; no vomiting ; } \\
\text { no jaundice. Mother and brother } \\
\text { developed slight jaundice. }\end{array}$ \\
\hline 10 & F., 7 & $2 \mathrm{~A}$ & 39 & - & $\begin{array}{l}\text { Headache; dizziness; vomited yellow } \\
\text { mucus; slight pyrexia; no jaundice. }\end{array}$ \\
\hline 11 & F., 9 & $3 \Delta$ & , & - & $\begin{array}{l}\text { Vomited mucus and bile; slight } \\
\text { pyrexia; slight jaundice of con- } \\
\text { junctivæ and skin. }\end{array}$ \\
\hline 12 & M., 9 & 4 & $"$ & - & $\begin{array}{l}\text { Nausea; no headache; no vomiting ; } \\
\text { jaundice doubtful. }\end{array}$ \\
\hline
\end{tabular}

that the child had the disease, for he gave it to his mother and brother at home, and they developed the typical jaundice. On the analogy of other epidemic diseases such cases would be expected to occur, but they are either unusual or more probably overlooked.

The rather numerous cases of gastro-enteritis noticed during the Bloemfontein epidemic were probably abortive cases; the cases of pharyngitis noticed by Cameron Gibson may have been, though this is less probable. One case was noted by Falkner at Toowomba. Apart from these I can find no record of any in the various epidemics at home or abroad. The Wealdstone epidemic establishes their occurrence on a firmer basis than before.

The disease appears to be most infectious in the prodromal period and in the early stages, but the virus may remain active and be transported to a distance. Instances of spread by this means have occurred several times, and a good example was 
published recently by Prosper Merklen under the title of "emotional jaundice." A girl was run into by a bicycle on Dec. 3rd, 1910 . On the 5th she had headache, nausea, and a temperature of $38^{\circ} 4^{\circ} \mathrm{C}$., and on the 6th jaundice. The jaundice only lasted seven or eight days, and on the 27th she went to stay with an uncle in the country in a household where there were four children. Two of these contracted the disease in a more severe form, one becoming ill on Jan. 8th and one on Jan. 17th, 1911. Another example of the virus remaining active was one I met with in 1912. In a family of 18 members the youngest child, aged 3 years, had catarrhal jaundice on March 6th, and six weeks later, on April 17th, the next youngest, a girl, aged $5 \frac{1}{2}$ years, was attacked. Schneekloth records that in a family two girls fell ill at eight days' interval, and an infant three months later. Krasnobaeff states that three brothers were attacked at intervals of three or four weeks, and then it was discovered that a child with jaundice had lived for a few days in the room at which they stayed. This proves conclusively that the virus can persist outside the body, though it is not improbable that carriers may play an important part in its dissemination.

Dr. Gibson thinks that there are two specific diseases described under the name "epidemic catarrhal jaundice," one attacking children and rarely affecting adults, the other affecting adults. It seems much more probable that the disease is usually confined almost entirely to people of one age owing to its slight infectivity. It attacks one form in a day school or one house in a boarding school. For instance, several boys in the sixth form of a public school were attacked two years ago, and none in any other form. In another, adults of similar age alone may be attacked as in the French barrack epidemics, in which young recruits usually suffer and in which a few of the dormitories alone are affected, but in one of which at least only old soldiers were attacked and the outbreak was confined to their special quarters. It is only in extensive epidemics that people of all ages are attacked.

The one possible mode of spread, except by the air, which would explain these epidemics, is by means of some biting insect. Mosquitoes, flies, and midges are excluded by the fact that it is not a summer disease; bedbugs and pediculi by the fact that it is as common amongst the better classes as amongst the poor. Fleas are unlikely to be the cause for the same reason, and in some instances I have been able to exclude them so far as they can be excluded. It is also unlikely because fleas are most common in July, August, September, and October, and least common in January, February, and March, the months in which catarrhal jaundice is most prevalent.

No other infectious disease was prevalent during either of these two epidemics, and they add to the evidence, which is steadily accumulating, that the disease is quite distinct and not merely a peculiar form of influenza, paratyphoid, or typhoid fever. I have adranced reasons elsewhere for attributing its occasional association with these diseases to coincidence. In one of my cases I had Widal's reaction done a fortnight after the jaundice had disappeared and it was negative. The positive agglutination tests with the bacillus typhosus and paratyphosus are probably due to the presence of bile in the blood, and no weight should be attached to a positive result until this is no longer present.
During the discussion on Dr. Guthrie's paper, already mentioned, Dr. R. C. Jewesbury mentioned the occurrence of epidemic jaundice in dogs. This was formerly held to be a severe form of distemper comparable to the jaundice which appears in the bad cases of yellow fever and relapsing fever, but it is more probably a distinct disease. Mr. Henry Gray gives an account of it in Hoare's "Text-book of Veterinary Medicine." $\mathrm{He}$ tells me that it is rarely seen in London, but that it occurs rather commonly in sporting dogs, especially after they have been in damp thickets, and causes a very heavy mortality. He is inclined to think that it is allied to or identical with the malignant jaundice investigated by Nuttall and proved to be due to a protozoon, piroplasma canis, conveyed by the bite of a tick. There seems to be no likelihood that it is the same disease which attacks man, and I can find no evidence that epidemics in man and in dog have occurred together.

In conclusion, I should like to thank Dr. C. W.F。 Young and his assistant, Dr. R. A. Askins, Dr. Scanlan, and Dr. Baker, and also the head masters and mistresses of the schools, for the great trouble they took in supplying me with information.

Bibliography.-Cockayne, E. A.: Quarterly Journal of Medicine, October, 1912, pp. 1-29. Falkner : Australasian Medical Gazet te, 1902 vol. xxi., p. 256. Gibson, Cameron: Public Health. March, 1914, p. 181 Guthrie. Leonard: Proceedings of the Royal Society of Medicine, vol. vi., No. 2, Section for the Study of Disease in Children, p. 48 Keynes, G. L. : St. Bartbolomew's Hospital Journal, June, 1914, p. 147 Merklen, Prosper: Bulletin de la Société de Pédiatrie de Paris, 1911 p. 99. Nuttall. G. H. F.: Journal of Hygiene, 1907, vol. iv., p. 219 , Nuttall and Graham-Smith: Ibir., 1905, vol. v., p. 237, and 1907, vol. vii., p. 257. Parkinson, J. Porter: Proceedings of the Roya Society of Medicine, vol. vii., No. 4, Section for the Study of Disease in Children, February, 1914, p. 75. Poignard, R.: Brit. Med. Jour,, 1912, vol. i., p. 72. Schneekloth: Thèse de Kiel, 19 co.

Harley-street, W.

\section{SOME PROBLEMS IN CARDIAC PHYSIOLOGY :}

CONTRIBUTIONS TO A STUDY OF THE RELATIONS WHICH EXIST BETWEEN THE VARIOUS CHAMBERS OF THE

$$
\text { MAMMALIAN HEART. }{ }^{1}
$$

BY A. F. STANLEY KENT, M.A. OXON.,

HENRY OVERTON WILLS PROFESSOR OF PHYSIOLOG $Y$ IN THE UNIVERSIT OF BRISTOL.

Probably all here are familiar with the history of the subject of this lecture, and are aware that before 1892 it was impossible to explain the action of the mammalian heart on the comparatively simple lines found adequate in the case of the heart of the frog, owing to the fact that any muscular connexion between auricle and ventricle in the mammal was absolutely denied. In 1892 it was shown that this idea was erroneous and that muscular connexion between auricle and ventricle did as a fact exist. In the following years the details of the connexion were worked out by various observers, and the band of tissue is now familiar to everyone as the auriculo-ventricular bundle. As is often the case with new knowledge, it was some time before the existence of the auriculo-ventricular bundle was used in explaining symptoms presented by clinical cases. Within the last few years, however, its importance has been fully recognised, and its presence has generally been referred to in explaining certain forms of cardiac irregularity. Certain difficulties have arisen in connexion with these explanations from time to time, and some have doubted whether the case

1 A lecture delivered before the University of Londen at South Kensington on June 18th, 1914. 